\title{
アトリウムの温熱環境に関する文献調査 \\ 垂直温度分布と空間構成の関連 \\ TREND IN THERMAL ENVIRONMENTAL DESIGN OF ATRIUM BUILDINGS IN JAPAN
}

\author{
吉 野 博*, 伊 藤 邦明*, 青笹 健** \\ Hiroshi YOSHINO, Kuniaki ITO and Ken AOZASA
}

\begin{abstract}
Various kind of atrium buildings have been constructed in Japan since 1982. Recently, there have been some measured data on thermal environment of atriums. This paper firstly describes the trends in the design and construction of atrium buildings, based on the design magazines. Secondly, the design methods of thermal environmental control of 21 atriums are classified, and measured data on vertical temperature profiles in the atrium are compared, referred to the technical papers. In summer, there is high temperature rise such as $60^{\circ} \mathrm{C}$ in the top of the atrium. The temperature profiles except below-roof area can be divided into three groups, as follows: 1)Little temperature gradient in case of the courtyard type with high ceiling. 2)High temperature gradient in cases of the greenhouse type with large glass area. 3)Moderate temperature gradient in other cases. In winter, there is little temperature for whole enclosure in all cases. But in many cases, the temperature decrease in the floor level area appears due to stack effect.
\end{abstract}

Keywords: Atrium, Vertical temperature gradient, Type of atriums, Literature survey アトリウム, 垂直温度分布, 空間構成, 文献調査

1.はじめに

1980 年代に入り、わが国においても様々なアトリウム を有する建物が建設されてきた。現在ではその総数も、 200 件以上にのぼる。こうしたアトリウムに関して、環 境工学的には以下のような特街を挙げることができる。 1)屋根、外壁にガラスが多用され、日射を始めとする外 部環境の影響を受け易い。そして、低い断熱性から、コ ールドドラフトを生じるなど、冷暖房負荷が大きくなる。 2)大空間であることが多く、上下温度差が大きくなり易 い。夏期にはアトリウム上部の温度上昇、冬期には煙突 効果による居住域環境の悪化が䀣念される。

また、アトリウムでは、空間上部にまで執務空間など が隣接することも多く、隣接空間への影䇾も懸念される。 近年はこうしたアトリウムについて、実測調査などが盛 んに行われ、温熱環境に関する資料も蓄積されてきてい る。しかし、アトリウムの形態は、規模、ガラス面のあ り方など様々であり、外部環境からの影響の程度、環境 調整手法なども異なり、一律に比較することは難しい。
そこで、本報では、温熱環境に関する資料の得られる 21 件の事例を対象として、アトリウムの空間構成に関し て分類を行い、それぞれについて環境調整手法、垂直温 度分布を比較する。そして、空間構成、環境調整手法と 垂直温度分布の関連を検討し、アトリウムの温熱環境の 特性を明らかにする事が本報の目的である注1。また、ア トリウム実施例の動向を把握し、本報で対象とする事例 の位置づけを行うために、建箘専門誌弪 2 に基づき、空間 構成等に関する調査も行った。

\section{2. アトリウム実施例の動向}

\section{1 調査概要}

1981 年 11 月から 1994 年 4 月までの建築専門誌注 2 に掲 載されたアトリウム事例について、表 1 に示す内容で調 查を行った。アトリウムを有する建物の総数は 202 件、 また複数のアトリウムを有する建物もあり、アトリウム 自体の総数は 216 件であった注3。
$*$ 東北大学工学部建築学科 教授・工博

** 東北大学工学部建築学科 大学院生
Prof., Dept. of Architecture, Faculty of Engineering, Tohoku Univ., Dr. Eng.

Graduate Student, Dept. of Architecture, Faculty of Engineering, Tohoku Univ. 
表 1 調査項目

\begin{tabular}{l}
\hline \hline 1: 名称 \\
2: 所在地 \\
3: 建物用途 \\
4: 竣工年 \\
5: アトリウムの空間構成 \\
(形態,ガラス壁面效,断面形式,頂部形式) \\
6: アトリウム利用目的 \\
7: 外部空間との開閉 \\
8: アトリウムの規模 \\
(容積,床面嘳,天井高,ガラス面㺓) \\
\hline \hline
\end{tabular}

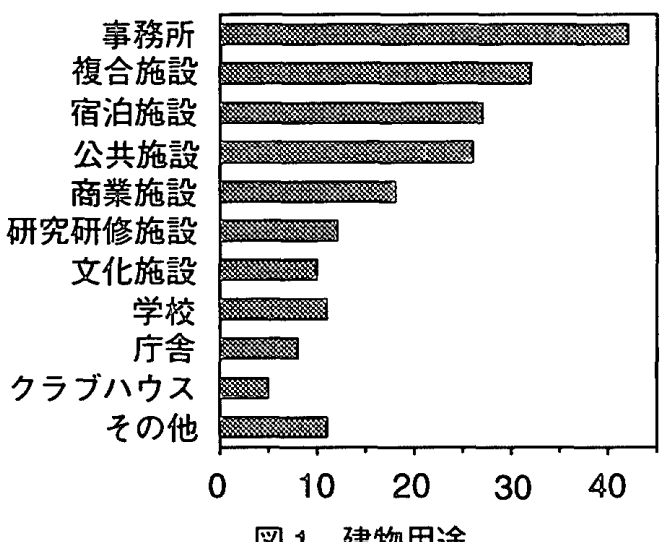

図 1 建物用途

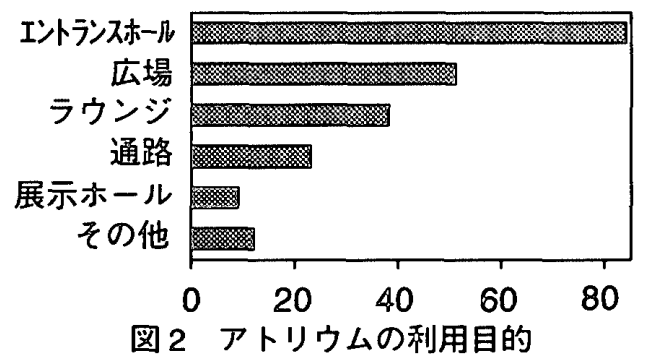

\section{2 建物用途、刹用目的}

アトリウムを持つ建物の主用途を図 1 に示す。事務所 が最も多く、全体の 20\%を占める。次いで、複合施設、 宿泊施設、公共施設が多く、以下、商業施設、研究 - 研 修施設と続く。図 2 は、アトリウムの利用目的を示した ものである。アトリウムの利用目的を一つに断定するこ とは難しいが、ここでは便宜的に六つに分類している。 エントランスホールとして利用される場合が最も多く、 以下広場、ラウンジと続き、不特定多数の人々が特に目 的を持たずに利用する場合が多いようである。

\section{3 建設数}

図 3 に 1981 年から 1993 年までのアトリウム建設数の 経年変化を示す。1980 年代は、年々建設数が増加してい たが、近年では横ばいとなっており、アトリウムを持つ 建物数で年 30 件前後となっている。

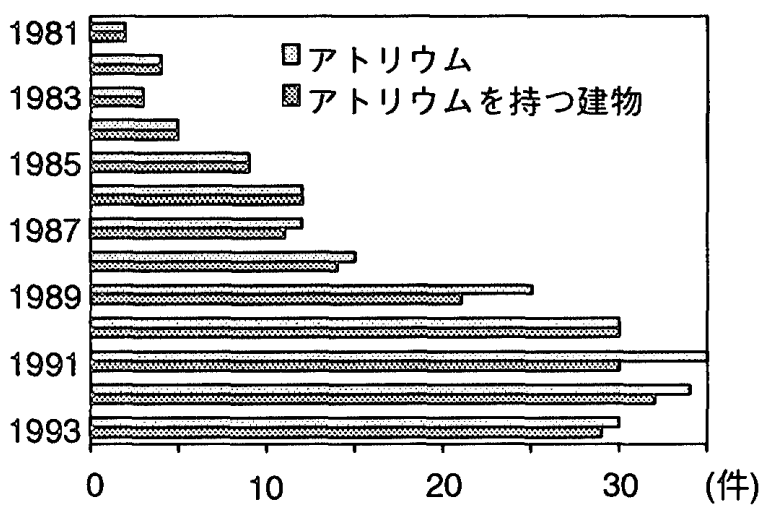

図 3 アトリウム建設数の経年変化
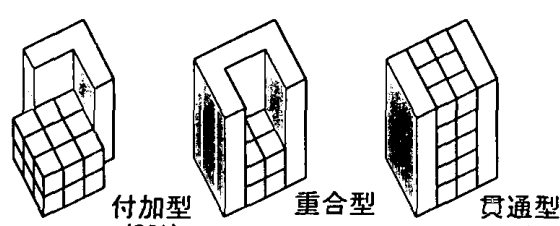

$(17.6 \%)$

(6\%)

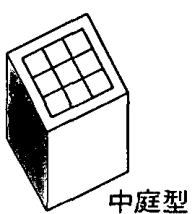

$(43.5 \%)$

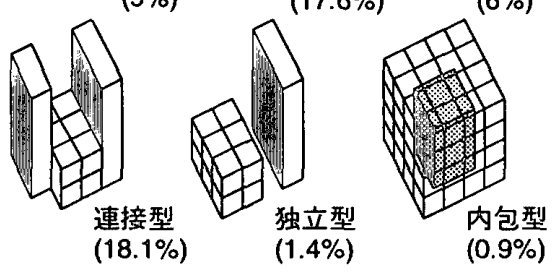

図4アトリウムの形態

2.4 アトリウムの形態、ガラス壁面の方位

R.サクソンは著書 ${ }^{33)}$ の中で、アトリウムの形態を九つ に分類しているが、本調㚗は国内事例を対象としており、 アトリウムの温熱環境との関連を検討することなどを考 虑して、アトリウムと主建物の関係、ガラス面のあり方 から図 4 に示す七つに分類した。また図 4 には、それぞ れの割合も併せて示す。約 40\%は主建物がアトリウムを 囲む中庭型となっている。次いで、アトリウムを主建物 が「コの字」に囲む重合型と、二つの建物をアトリウム がつなぐ連接型が多くなっている。図 5 は、ガラス外壁 の設けられた方位を示したものである。ガラス壁面数が 1 面の場合、北、東が多く、南がそれに続く。2 面では、 北・南、東・西と対に配されることが多く、3 面では南 を中心とした事例が最も多くなっている。しかし、環境 的には不利とされる北あるいは、西面に大きなガラス面 を設けている事例も見られる。

\section{5 アトリウムの規模}

アトリウムの床面積と容積、天井高の関係について図 6 に示す。多くの事例は、床面積 $3000 \mathrm{~m}^{2}$ 以下、容積は $20000 \mathrm{~m}^{3}$ 以下となっている。天井高については $10 \sim 30 \mathrm{~m}$ の 5 階前後の比較的低層のものが多くなっている。なお 二重丸で示したものは、次章以降で取り上げる 21 件の事 例である。 


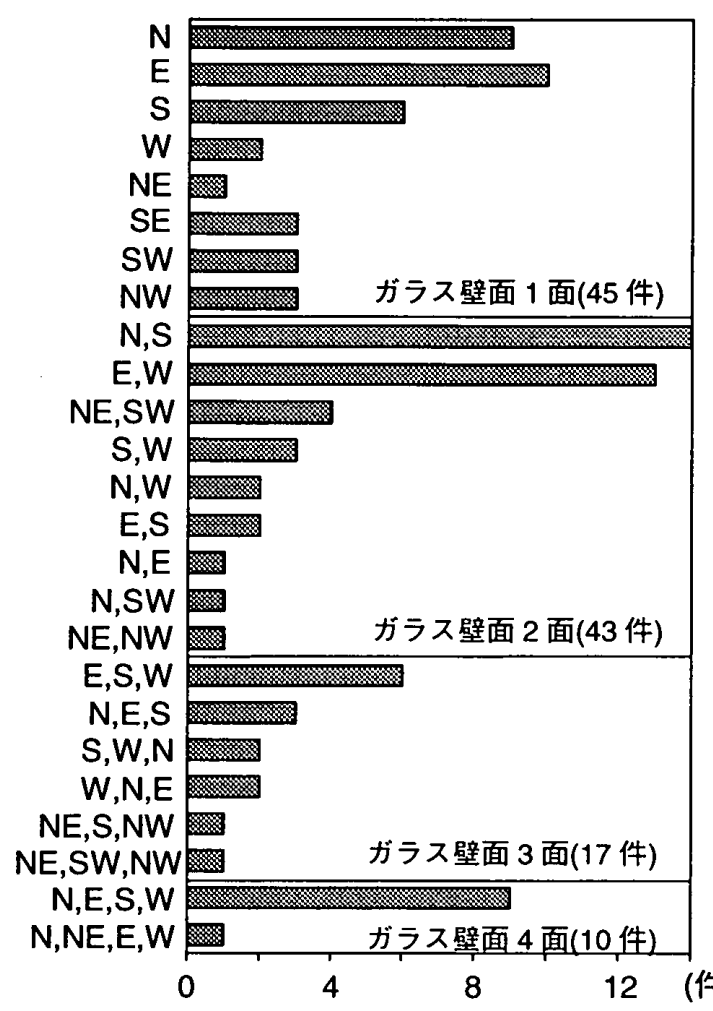

図 5 ガラス外壁面の方位
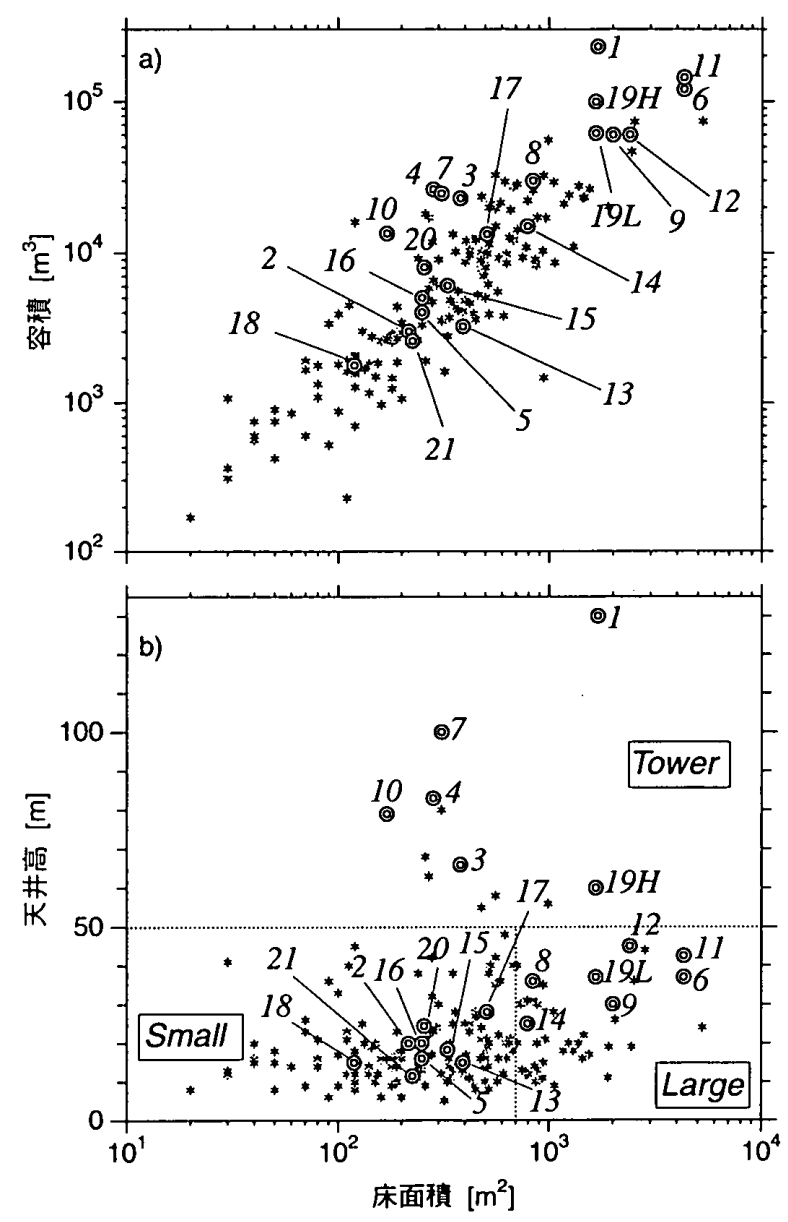

図6 アトリウムの規模

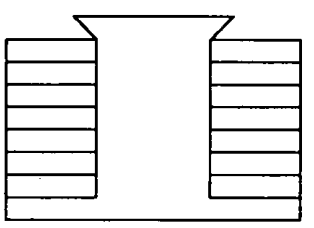

I. 分離型

$2,15,17,19 \mathrm{H}, 19 \mathrm{~L}, 21$

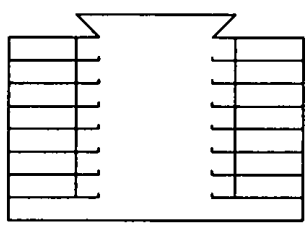

III. 廊下一体型 $7,13,16,18$

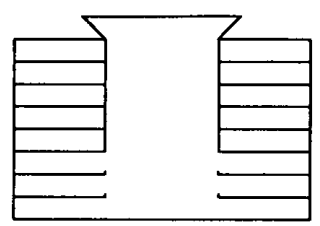

I1. 分離型

(下層部は一体型)

$1,3,4,6,9,11,14$

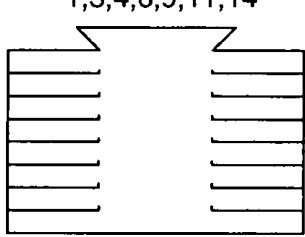

IV. 居窒一体型

$5,8,10,12,20$
図 7 断面形式による分類

3. アトリウムの温熱環境

\section{1 調査概要}

本章では実施例の内、実測調査の結果が公表され、温 熱環境に関するデータの得られる 21 件のアトリウム注 4 を対象とする。この 21 件のアトリウムに関して、1)建築 専門誌注 2 による空間構成の分類、2)建築設備関連雑誌壮 5 による環境調整手法の分類を行い、3)実測調査に関する 文献注6により夏期・冬期の垂直温度分布を比較し、空間 構成との関連を検討した。なお、対象事例の建物概要を 表 2 にまとめる。

3.2 空間構成の分類

まず対象事例の規模に関して、床面積と容積、天井高 の関係を図 6 に二重丸で示す。対象事例は比較的大規模 なものが多く、特に、事例 $1 、 6 、 11$ は国内最大級の規模 となっている。

また、アトリウムの形態を図 4 に従い分類すると、表 2 の中に示したようになるが、同じ中庭型の形態でも、高 層の事例と低層の事例とでは、日射の影響は異なるよう に、規模の違いもアトリウム内の環境に影響していると 考えられる。そこで、アトリウムの規模に関して、図 6 の分布状態をもとに、以下に示すように分類した。

Tower type: 天井の高い塔状のアトリウム

Large type: 床面積、容積の大きなアトリウム

Small type: 比較的低層で小規模なアトリウム

一方、アトリウムと隣接空間との関係については、仕 切りの位置や有無により図7に示す通り四つに分類した。

\section{3 環境調整手法}

アトリウムでは、前述のように上下温度差がつきやす い。そこで、アトリウムの環境調整では、省エネルギー といった点から、ある程度の上下温度差を許容し、頂部 にはあらかじめ、熱だまりとするための空間を設け、空 調は底部の居住域のみとする場合が多い。そして、排熱 
表 2 対象事例の建物摡要

\begin{tabular}{|c|c|c|c|c|c|}
\hline $\begin{array}{l}\text { 亨例 } \\
\text { No }\end{array}$ & 所在地 & 主用途 & 形態 & \begin{tabular}{|c|c|c|} 
壁面数 \\
\end{tabular} & 剂用目的、その他 \\
\hline 1 & 東京 & 事務所 & 中庭型 & 0 & イベント広場として利用するエントランスホール。休䕀スペース有。 \\
\hline 2 & 東京 & 庁舎 & 中庭型 & 0 & 床,壁面に不材を使用したエントランスホール。 \\
\hline 3 & 秋田 & 複合施設 & 中庭型 & $(1)^{*}$ & 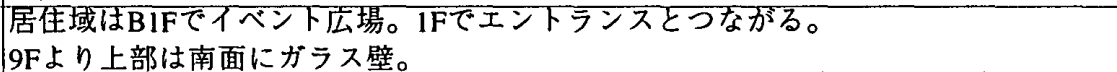 \\
\hline 4 & 東京 & 事務所 & 中庭型 & 0 & 居住域はB1Fで休㦝スペース有。1Fでエントランスとつながる。 \\
\hline 5 & 東京 & 事務所 & 中庭型 & 0 & $\begin{array}{l}\text { L字型の平面を持ち,一方は受付のあるエントランスホール, } \\
\text { もう一方は打ち合わせスペース。 }\end{array}$ \\
\hline 6 & 浦安 & 宿泊施設 & 中庭型 & 0 & レストラン,店舗の配されたラウンジ。 \\
\hline 7 & 東京 & 事務所 & 中庭型 & 0 & エントランスホールとエレベーターホールをつなぐ受付の配された通路空間。 \\
\hline 8 & 浜松 & 複合施設 & 重合型 & 1 & イベント広場として利用するエントランスホール。東面がガラス壁。 \\
\hline 9 & 東京 & 事務所 & 連接型 & $2(4)^{*}$ & 各種店舗と接する広場空間。妻側の南北面と,平側の東西面の一部がガラス壁。 \\
\hline 10 & 東京 & 事務所 & 貫通型 & 1 & 底面はB1Fで,1Fでエントランスとつながる通路空間。東面がガラス壁。 \\
\hline 11 & 東京 & 複合施設 & 連接型 & 2 & イベント対応型の広場空間。東,南面の一部がガラス壁。 \\
\hline 12 & 東京 & 事務所 & 重合型 & 1 & アトリウム内2Fにラウンジのあるエントランスホール。東面はガラス壁。 \\
\hline 13 & 横浜 & 事務所 & 中庭型 & 0 & エントランスホール。 \\
\hline 14 & 大阪 & 事務所 & 付加型 & 3 & エントランスのある広場空間。西,南北面はガラス壁。 \\
\hline 15 & 東京 & 複合施設 & 付加型 & 4 & 休喤スペースのある通路空間。西面は全面,南北面は半面,東面は3F以上がガラス壁。 \\
\hline 16 & 北海道 & 庁舎 & 中庭型 & 0 & エントランスホール。 \\
\hline 17 & 千葉 & 複合施設 & 連接型 & 2 & エントランスホール。妻側の北東,南西面がガラス壁。 \\
\hline 18 & 横浜 & 独身寮 & 中庭型 & 0 & エントランスホール。 \\
\hline $19 \mathrm{H}$ & 千葉 & 事務所 & 中庭型 & 0 & 途中階に中空庭園,中央にエレベーターシャフトのある通路空間。 \\
\hline $19 L$ & 千葉 & 事務所 & 中庭型 & 0 & 中央にエレベーターシャフトのある通路空間。 \\
\hline 20 & 千葉 & 商業施設 & 中庭型 & (4)* & 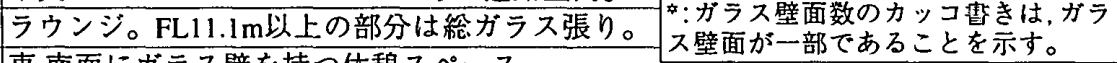 \\
\hline 21 & 大阪 & 事務所 & 付加型 & $\underline{2}$ & 東,南面にガラス壁を持つ休䄭スペース。 \\
\hline
\end{tabular}

のための頂部の換気、日射遮蔽などの手法も併用される。 アトリウムの環境調整手法は以下のように分類すること ができる。また図 8 は、環境調整手法をモデル化したも ので、表 3 に各事例の調整手法をまとめた。なお、表中 のアルファベットは、図 8 における各手法を示す。

\subsection{1 居住域の環境調警}

居住域の環境調整は主に、図の $\mathrm{a} \sim \mathrm{c}$ の手法によって行 われる。また、それぞれの手法を併用している事例も多 い。特に、冬期については多くの事例で床暖房が併用さ れている。

\subsection{2 頂部における環境調整}

頂部では、熱だまりの熱を排出するために、温度差を 活かした自然換気、あるいはファンによる機械換気が行 われることが多いが、事例 4、7では、ファンコイルユニ ットによる冷房を行っている。また、事例 16、18、21 で は頂部の排熱のみならず、アトリウム全体の環境調整に 自然換気を活用している。

\subsection{3 日射遮荡}

透過日射を低減するため、ガラス屋根の内側にブライ ンド、遮光板、あるいは垂れ幕などが設置される。日射 遮蔽は外部で行う方が効果は大きいが、事例 21 のみ屋根、 壁面の外部に遮蔽幕が設置されており、他の事例はアト リウム内に設置されている。また事例 15、19L はガラス 屋根を持たない遮蔽型のアトリウムである。

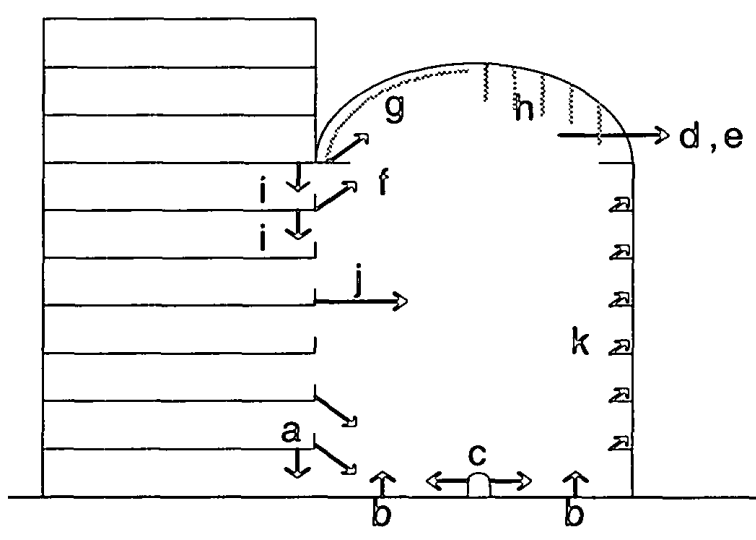

居住域の瓄境調整

a: アトリウム壁面、橓接空間天井からの吹出

b: 床暖冷房

c: 自立型空調機によるスポット空調

頂部の瓄境調整

$\mathrm{d}$ : 自然換気

e: 機被換気

i: FCU冷房

日射遮蔽

g: ブラインド

h: 垂れ幕、遮蔽幕

その他

$\mathrm{i}:$ アトリウムサイドの吹出（エアカーテン）

$\mathrm{j}$ : 中間階での横向き吹出

$\mathrm{k}$ : ガラス面への温風吹出

图8 アトリウムの櫝境調整手法 
表 3 対象事例の環境調整手法 (表中のアルファベットは図8の各手法を示す。)

\begin{tabular}{|c|c|c|c|c|c|c|c|}
\hline 事例 & & & 夏期 & & 冬 & 期 & 閉口竞 その他 \\
\hline No & 居住域 & 頂部 & 遮蔽 & その他 & 居住域 & その他 & 形山訲、てひ他 \\
\hline 1 & - & $(d)^{* 1}$ & - & - & $b^{*}$ & - & 頂部に換気口有。*余熱による床暖房のみ。 \\
\hline 2 & a & $\mathrm{d}$ & - & - & a & & 頂部に自然換気用ダクト有。 \\
\hline 3 & a & (d) & - & - & $a, b$ & - & 1F部に給気口,頂部に排気口有。 \\
\hline 4 & $\mathrm{a}$ & $(\mathrm{d}), \mathrm{f}$ & - & - & a,b & - & $\begin{array}{l}\text { 中層部 }(18 \sim 32 \mathrm{~m}) \text {,上部 }(81 \mathrm{~m}) \text { に開口有。 } \\
\text { 屋根面の一部に和紙入りガラスを使用。 }\end{array}$ \\
\hline 5 & $\mathrm{a}$ & $\mathrm{e}$ & - & $\mathrm{i}$ & $\mathrm{a}$ & $\mathrm{j}$ & 頂部に排気ファン有。 \\
\hline 6 & $\mathrm{a}$ & $\bar{d}$ & $\mathrm{~h}$ & $\mathrm{i}$, 冷水池 & $a, b$ & - & 頂部に排気ダンパー有。 \\
\hline 7 & $\mathrm{a}$ & (d),f & 二 & - & $\mathrm{a}$ & - & 頂部に排煙口有。 \\
\hline 8 & c & (d) & - & $\mathrm{i}$ & c & & 頂部に排煙空有。 \\
\hline 9 & b,c & (d) & $\mathrm{g}$ & - & b,c & - & 頂部に排煙口有。スポット空調。 \\
\hline 10 & a & - & $\mathrm{g}$ & $\mathrm{i}$ & $a, b$ & - & 熱だまりのための空間なし。 \\
\hline 11 & $a, b$ & $\mathrm{e}$ & $\mathrm{h}$ & - & $a, b$ & - & $25,000 \mathrm{~m}^{3} / \mathrm{h}$ の第一種換気。 \\
\hline 12 & $\mathrm{a}$ & (d) & - & $\mathrm{i}(8 \mathrm{~F})$ & $\underline{a}$ & $\mathrm{k}$ & 頂部に換気口有。 \\
\hline 13 & $a$ & e & $\mathrm{g}$ & $\mathrm{i}($ 最上部) & $a, b$ & - & 頂部で第一種換気。熱だまりのための空間なし。 \\
\hline 14 & a,c & $\overline{\mathrm{d}, \mathrm{e}}$ & & - & a,c & - & 側壁に排煙口,頂部に排気ファン有。 \\
\hline 15 & $\mathrm{a}$ & $\mathrm{e}$ & 遮蔽 & $\mathrm{i}(5 \mathrm{~F})$ & $\mathrm{a}$ & & 天井に排気ファン有。ガラス屋根の無い遮薢型。 \\
\hline 16 & - & d & - & - & $a^{*}$ & - & 上部に排煙口有。*補助的な暖房のみ。 \\
\hline 17 & $\mathbf{a}$ & (d) & $\mathrm{h}$ & - & a & - & 頂部に排煙空有。 \\
\hline 18 & a & d & - & - & $a, b$ & - & $\begin{array}{l}\text { トップライト部開放可。夏期は1F給気口,トップライト部による自 } \\
\text { 然擙気を主とし，冷房は補助的とする。熱だまりのための空間なし。 }\end{array}$ \\
\hline $19 H$ & a,c & (d) & - & - & $\mathrm{a}, \mathrm{c}$ & - & 頂部に換気口有。 ${ }^{*} 1:$ カッコ書きは, 頂部の開口部を開放 \\
\hline $19 L$ & a & - & 遮蔽 & - & a & - & することで,自然換気が可能であるこ \\
\hline 20 & $\mathrm{a}, \mathrm{b}$ & $\mathrm{f}$ & $\mathrm{g}$ & 冷水池 & $\mathrm{a}, \mathrm{b}$ & $\mathrm{k}$ & $11 \mathrm{~F}$ の一部にスポット空調。 とを示す。 \\
\hline 21 & - & d & $\mathrm{h}($ 外) & - & 一 & 一 & 外部に遮蔽幕を設置。自然換気を主とする環境調整。 \\
\hline
\end{tabular}

\subsection{4 その他の手法}

廊下一体、居室一体型といった断面形式のいわゆるオ ープンタイプのアトリウムでは、エアカーテンとして手 法 $\mathrm{i}$ を併用することが多い。また手法 $\mathrm{j}$ は、上昇流を抑制 するために、手法 $\mathrm{k}$ は、ガラス面でのコールドドラフト、 結露を防止するために行われる。

以上のように環境調整は機械設備に負うところが大き いが、中には、自然換気や、建築的工夫を活用して環境 調整を行う事例も見られる。事例 1 では、基本的に環境 調整は行わず、余熱による床暖房のみで、環境は成りゆ きとしている。事例 18 では、夏期については自然換気を 主とし、空調は簡易的なものとなっている。また事例 16 は北海道に位置しており、冬期は補助的な暖房を行って いるが、夏期は、自然換気による環境調整のみである。 事例 21 は大阪に位置し、外部と同程度の環境を目標とし ており、夏期は外部遮蔽幕による日射遮蔽と自然換気に よる環境調整のみ、冬期は成りゆきとしている。

\section{4 垂直温度分布の特徴}

\subsection{1 夏期}

夏期の垂直温度分布について、各事例の最も温度が低 下している夜間 $(0: 00$ 7:00) と、最も温度が上昇してい る日中（12:00～15:00）とに分けて、図 9、10に示す。図 中には、夜間については測定時刻を、日中についてはア トリウム形態、測定条件を事例番号と共に示す。また空 調の有無、あるいは自然換気の有無といった状態で測定
が行われている事例もあり、それぞれ図 11 に示す。これ らの垂直温度分布は、いずれも文献から得られるデータ をもとに描いたものである。

(1)夜間 図 9 (a) ( c)に夜間の垂直温度分布の比較を示 す。ほとんど上下温度差がなく、ほほ一直線の温度分布 となっている事例が多い。その中で事例 12 は、頂部の温 度が上昇しているが、これは測定時刻が 0:00であり、日 中暖められた空気が上部にたまっているためで、明け方 にかけて温度は低下していくものと考えられる。また、 事例 8、9は、上下温度差が多少大きくなっているが、共 にガラス面の割合が大きく、測定時刻が 7:00であるため、 日射の影響を受けているのではないかと考えられる。

(2)日中 日中の垂直温度分布の比較を各形態ごとに、図 10 (a) 〜 (d)に示す。各事例とも通常の使用状態（空調、換 気など）での測定結果である。なお、図中のカッコ内の 中 0、付 3 等はアトリウム形態とガラス壁面数を示す。 また、AC、NV、MV、SC はそれぞれ空調運転、頂部で の自然換気、機械換気、日射遮蔽が行われていることを 表わし、SH はガラス屋根のない遮蔽型のアトリウムを意 味する。夜間の温度分布に比べ、どの事例も大きな上下 温度差が生じており、ばらつきも大きくなっている。多 くの事例は、頂部で温度が急上昇しており、熱だまりの 形成が確認できる。また、居住域の温度は、空調のない 事例 21 を除き、 25 C前後となっている。次に、各 Type ごとに考察する。 

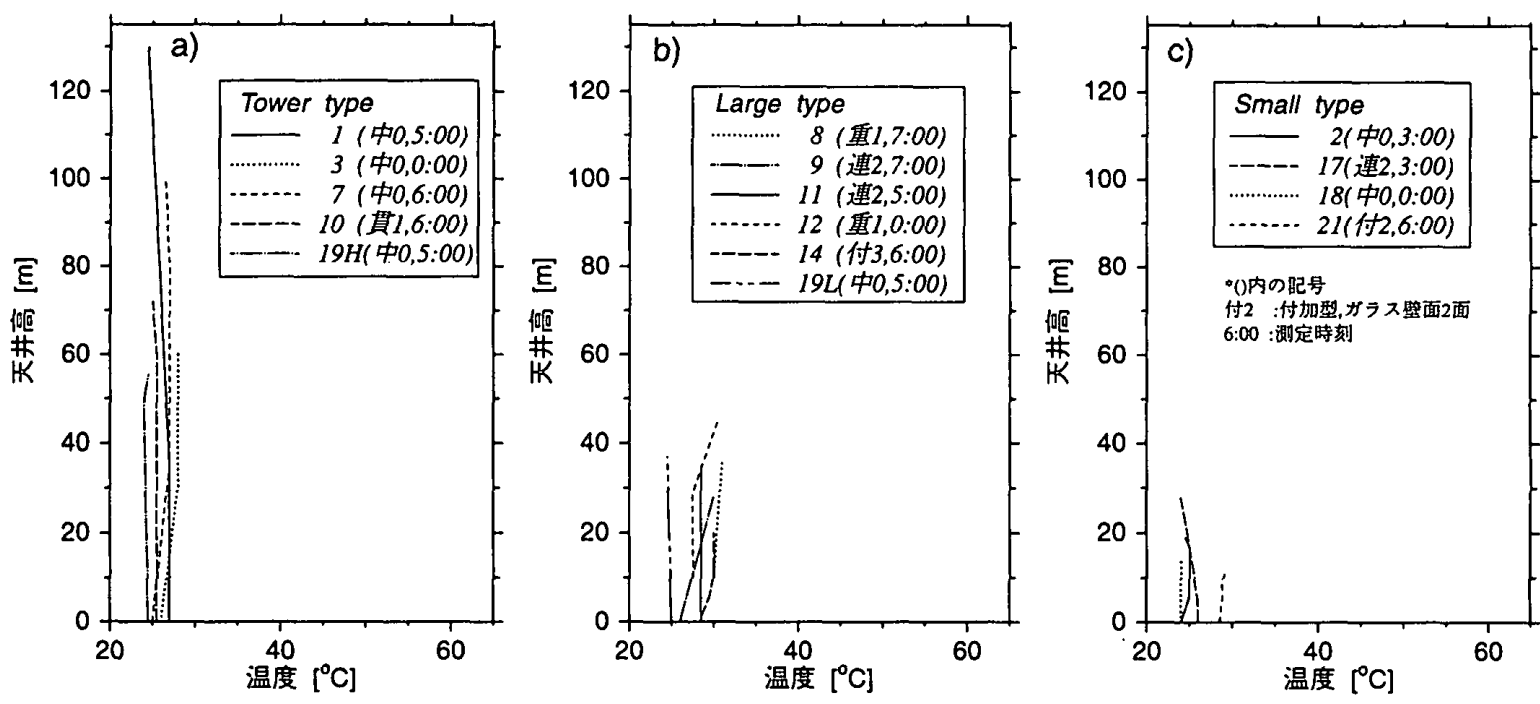

图 9 夏期垂直温度分布（夜間）
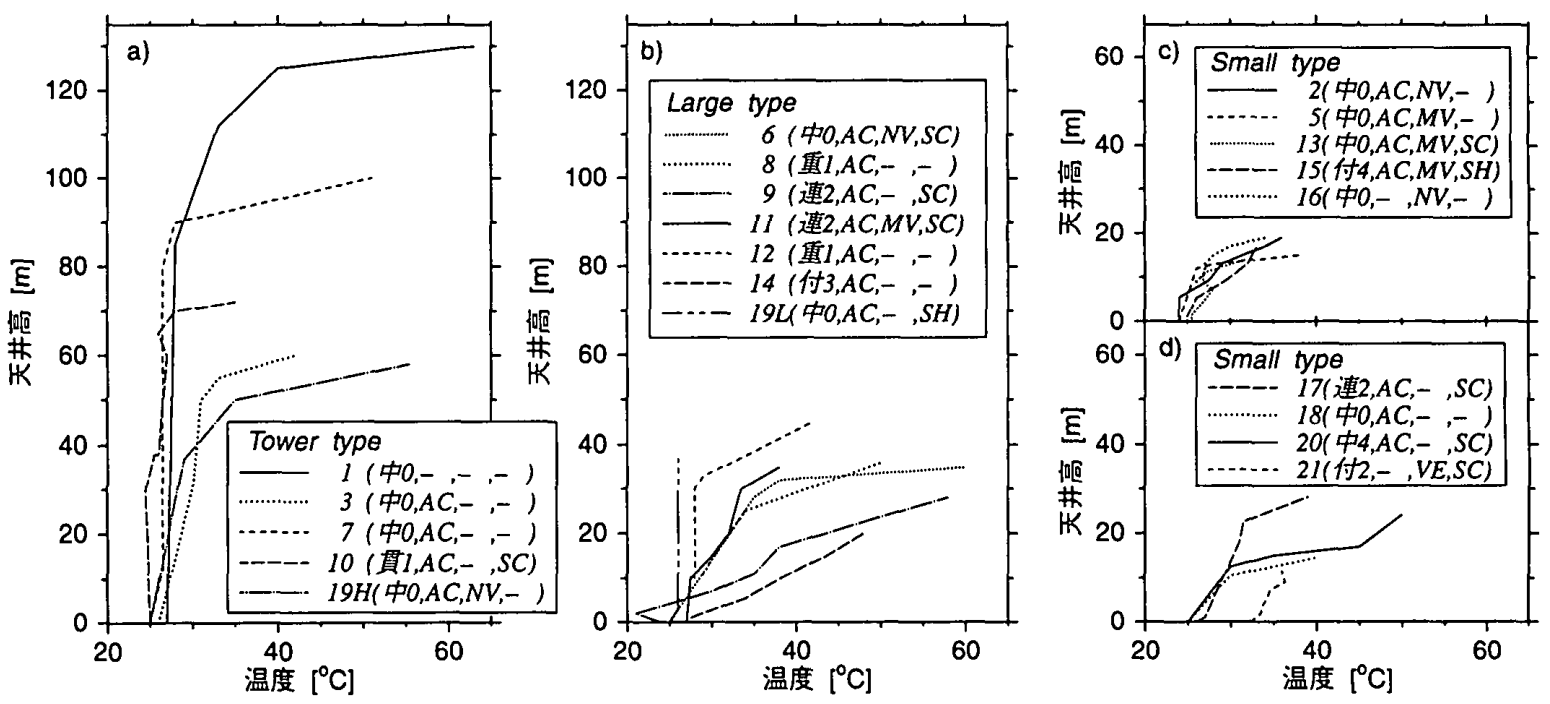

図 10 夏期垂直温度分布（日中）
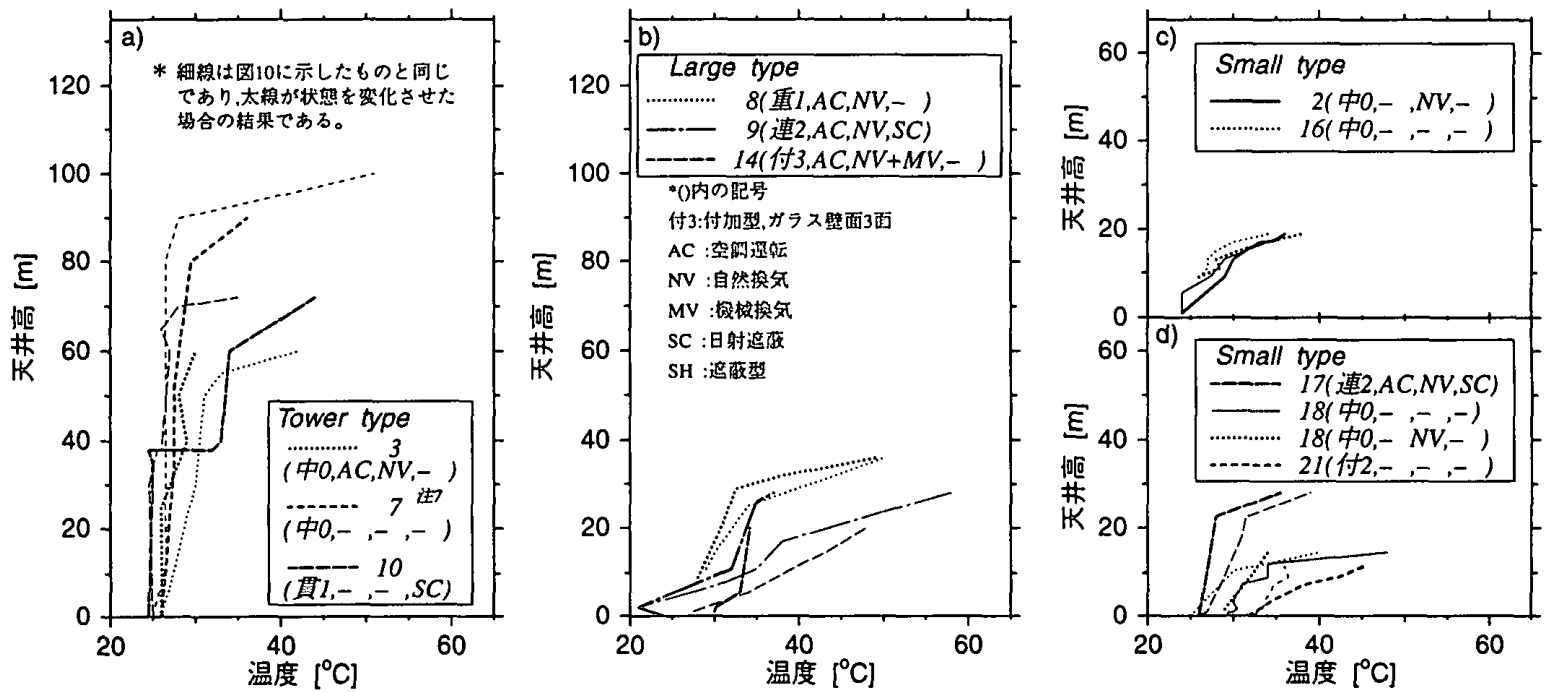

図 11 空調の有無、自然換気の有無 
表 4 高温域における隣接空間との関係

\begin{tabular}{|c|c|c|c|c|c|c|c|}
\hline \multirow{2}{*}{$\begin{array}{l}\text { 事例 } \\
\text { No }\end{array}$} & \multicolumn{4}{|c|}{ 空間構成 } & \multirow{2}{*}{$\begin{array}{l}30^{\circ} \mathrm{C} \text { 以上と } \\
\text { なる位置 }\end{array}$} & \multirow{2}{*}{$\begin{array}{l}0^{\circ} \mathrm{\circ} \text { C以上となる位置での } \\
\text { 隣接空間との関係 }\end{array}$} & \multirow{2}{*}{$\begin{array}{l}\text { 参考文献 } \\
\text { 番号 }\end{array}$} \\
\hline & 形態 & 規模 & 断面 & 階数 & & & \\
\hline 1 & 中0 & $\mathrm{T}$ & II & $1-30$ & $28 \mathrm{~F}$ & 4F以上は閉鎖 & 1 \\
\hline 2 & 中0 & $S$ & I & $1-4$ & $4 \mathrm{~F}$ & 3F以上は閉鎖 & 2 \\
\hline 3 & 中0 & $T$ & II & $\mathrm{B} 1-12$ & $11 \mathrm{~F}$ & 3F以上は閉鎖 & 3,4 \\
\hline 4 & 中0 & $\mathrm{T}$ & II & $1-14$ & - & - & 5 \\
\hline 5 & 中0 & $S$ & IV & $2-5$ & 熱だまり & - & 6 \\
\hline 6 & 中0 & $\mathrm{L}$ & II & $3-12$ & $7 \mathrm{~F}$ & 7F以上は閉鎖 & 7,8 \\
\hline 7 & 中0 & $T$ & III & $1-21$ & 熱だまり & - & 9,10 \\
\hline 8 & 重1 & L & IV & $1-8$ & $5 F$ & $\begin{array}{l}\text { 各階通路とは吹出空気により分離 } \\
5,6 \mathrm{~F} \text { にイベント時に客席となるテラスあり }\end{array}$ & 11 \\
\hline 9 & 連2 & $\mathrm{L}$ & II & $1-4$ & $3 \mathrm{~F}$ & 2F以上は閉鎖 2Fに通路と休憩スペース、3Fに通路あり & 12 \\
\hline 10 & 貫 1 & $\mathrm{~T}$ & IV & B1-21 & 熱だまり & - & $13,14,15$ \\
\hline 11 & 連2 & $\mathrm{L}$ & II & $1-7$ & $4 \mathrm{~F}$ & 1面は閉鎖、他の壁面は4 F 以上が閉鎖 & 16 \\
\hline 12 & 重1 & L & N & $1-9$ & 熱だまり & - & 17,18 \\
\hline 13 & 中0 & $\mathbf{S}$ & III & $1-4$ & 熱だまり & - & 19,20 \\
\hline 14 & 付3 & $\mathrm{L}$ & II & $1-5$ & $2 \mathrm{~F}$ & 2Fに通路あり & 21 \\
\hline 15 & 付 4 & $S$ & $\mathrm{I}$ & $1-5$ & $3 \mathrm{~F}$ & 2,5Fにブリッジあり & 22 \\
\hline 16 & 中0 & $S$ & III & $1-4$ & $4 \mathrm{~F}$ & 各階とも一部がアトリウムに開放 & 23 \\
\hline 17 & 連2 & $S$ & $\mathrm{I}$ & $1-5$ & $4 \mathrm{~F}$ & $2 \mathrm{~F}$ 以上は閉鎖 & 24 \\
\hline 18 & 中0 & $\mathrm{S}$ & III & $1-5$ & $5 \mathrm{~F}$ & 各階廊下がアトリウムに開放 & 25,26 \\
\hline $19 H$ & 中0 & $\mathbf{T}$ & $\mathrm{I}$ & $15-26$ & $23 \mathrm{~F}$ & 各階とも閉鎖 & 27,28 \\
\hline $19 L$ & 中0 & $\mathrm{L}$ & $\mathrm{I}$ & $2-9$ & なし & - & 27,28 \\
\hline 20 & 中4 & $\mathbf{S}$ & IV & $9-11$ & 熱だまり & - & 29 \\
\hline 21 & 付 2 & $\mathrm{~S}$ & $\mathrm{I}$ & $1-2$ & $1 \mathrm{~F}$ & 2Fにブリッジあり、各階とも閉鎖 & - \\
\hline
\end{tabular}

まず、Tower type の事例について、事例 10 はスリット 状のガラス面を 1 面持つが、その他は中庭型の形態であ る。頂部温度は、60を越える事例 1 を始めとしてかな りの高温となっているが、頂部の熱だまり以外は、上下 温度差が小さく安定している。これは、空間上部より下 の位置には日射が到達しにくいこと、アトリウムの周囲 を執務空間のような炆調空間に曲まれていることなどに よるものと思われる。

次に、Large type は、頂部の熱だまりでは Tower type と 同様に、高温となっているが、熱だまり以外の部分にお いても、温度が上昇して温度勾配がついている事例が多 い。特に、連接型、付加型の形態である事例 9、14 は、 空間全体に渡って、大きな温度成層が生じている。一方、 事例 12 は熱だまり以外の温度差が小さく安定している が、これはオープンタイプのアトリウムであるために空 調空間との空気の混合や、台形の断面を持つ形状で頂部 の面積が小さいことなどによるのではないかと思われる。 また、事例 19L はガラス屋根のない遮蔽型のアトリウム であり、ほぼ上温度差のない環境になっており、事例 11 は頂部温度の上昇が抑えられているが、これは第一種 換気や日射遮蔽の効果と推定される。

そして、Small type の事例についても、頂部で温度が急 上昇しているが、頂部の換気を行っている事例も多く、 事例 20 を除けば $40^{\circ} \mathrm{C}$ 以下であり、他の Type に比べると 温度上昇が抑えられている。頂部以外についてみると、
中庭型の内、事例 2、5 は、空調域で温度差が小さく安定 しているが、その他の事例は、緩やかな温度勾配が付い ている。また、付加型の事例について、事例 15 は、アト リウム全体の温度勾配が大きくなっているが、天井はガ ラスではなく、天井部で機械換気を行っているため、頂 部温度の上昇は比較的抑えられている。一方、事例 21 は、 日射遮蔽と自然換気のみで空調設備が無く、空間全体の 温度が、高温側へシフトしているが、居住域は、外気と 同等か、やや低い温度となっている。

(3)空調の有無、自然換気の有無による比較 日中の垂直 温度分布に関して、空調の有無、自然換気の有無による 比較を図 11 に示す。事例 2、7、10、18 では、空調を停 止した状態での実測が行われており、事例 16、21 は空調 設備のないアトリウムである。空調停止時、事例 2 では 上部温度に変化はないが、下層部の温度は上昇し、高さ に応じた温度成層が生じている。事例 7 注7では下層部に 違いはみられないが、熱だまりとなる高さが低下してい る。事例 10 は、アトリウム中間階に防火区画のため網入 りガラスが設置され、アトリウムは上下二つに分けられ ている。その内下層階は通常空調、上層階が非空調とな っており、上層階では全体的に $10^{\circ} \mathrm{C}$ 程上昇している。

次に、自然換気の有無に関して、事例 3、8、9、14、 17、18では、頂部の排煙口や換気口による自然換気を行 った状態での測定が、事例 16、21 では自然換気のない状 態での測定が行われている。自然換気を行った場合には、 
ほとんどの事例で上層部の温度が低下している。特に事 例 3 では、頂部温度が約 $40^{\circ} \mathrm{Cから} 30^{\circ} \mathrm{C}$ に、事例 9 では約

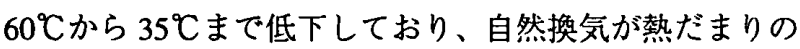
排熱に有効であることが分かる。自然換気により上層部 の温度は低下するが、事例 3、9、17、18 の場合、下層部 の温度の変化は小さい。これに対し事例 14、21 では、ア トリウムの全体の温度が低下するものの、底部の居住域 では逆に温度が上昇している。また事例 8 は、開口部が 熱だまりよりも低い位置にあり、開口部付近の温度は低 下するが、熱だまりの温度は大きな変化がない。このよ うに、頂部での自然換気は、熱だまりの紘和に有効であ ると言えるが、開口部より高い位置にある空間への影響 が小さく、また、居住域近くに開口部がある場合、外気 侵入により居住域温度の上昇を招くこともあり、自然換 気を行う際には開口部の位置に配慮する必要があるとい える。また、事例 18 では、空調運転時、空調停止時、そ して自然換気のみ行っている場合に、それぞれ測定が行 われているが、空調停止時は、アトリウム内の温度が全 体的に高温側へシフトしており、居住域は約 $30^{\circ} \mathrm{C} 、$ 頂部 は $45^{\circ}$ Cを越える。一方、自然換気を行った場合、頂部温 度は35゚以下にまで低下し、居住域においても、若干温 度が下がる。

(4)高温域におけるアトリウムと隣接空間との関係 アト リウムでは、ホール、体育館といった大空間に比べ、高 温となる上層部の周囲にも居住空間が配されることが多 い。そのため、隣接空間の環境に悪影響を及ぽすことも 考えられる。特に、オープンタイプアトリウムの場合、 アトリウムから隣接空間へ直接、熱気が侵入することも 懸念される。そこで、図 8 に示した夏期の垂直温度分布 から、各事例の $30^{\circ}$ C以上となる高さを調べ、高温域での アトリウムと陊接空間との関係について検討する。表 4 に各事例の空間構成とともに調査結果を示す。事例 5、7、 10、12、13、20は、いずれもオープンタイプのアトリウ ムであるが、30゚以上となる位置は熱だまりの中である。 その他の事例は、周囲に隣接空間のある高さで $30^{\circ} \mathrm{C}$ 以上 となっているが、その多くは壁、ガラス空によってアト リウムと橓接空間とは分離されている。また、事例 8 は オープンタイプであるが、整接空間とはエアカーテンに よって分離されている。これに対し、事例 16 では、30 以上となる空間でも一部がアトリウムに開放されている。

アトリウム内には通路、ブリッジなどが設けられるこ とも多く、事例 8 ではイベント時に客席となるテラスが、

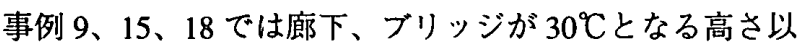
上の位置に設けられている。また事例 21 は、空調設備が なく、外部と同程度の環境を実現するいう環境設計がな されているため、アトリウム全体が $30^{\circ} \mathrm{C}$ 以上となってい るが、これらは居住空間とすると、やや不快であると言 える。事例 6 では、30となる高さによって、ガラス空
の開閉を決定しているが、こうした断面形式の決定は防 災上の問題の方が大きいように思われる。

\section{4 .2 冬期}

冬期の垂直温度分布についても、夏期同様、夜間 $(0: 00$ ～7:00）と日中（12:00～15:00に分けて、図12、13に示 す。なお、夜間については、事例番号と測定時刻を、日 中については、事例番号とアトリウムの形態、測定条件 （FH は床暖房を示す）を図中に示す。

(1)夜間 多くの事例で、アトリウム中層部には上下温度 差がなく、頂部、下部の温度がそれよりも低下する「弓 形」の温度分布となっている。事例 9 はこうした温度分 布の典型的な形である。これに対し、事例 $1 、 17$ などは、 アトリウム下部から高さとともに温度が低下する温度分 布となっており、事例 4 ではアトリウム下部の温度のみ 若干高くなっている。また事例 7 の下層部、事例 14 では 他の事例に比べ、温度低下が著しいが、事例 7 の測定は 月曜日に行われており、休日の間に空間が冷やされたた め、そして、事例 14 は 3 面がガラスで覆われた付加型の アトリウムであるためと思われる。

(2)日中 夏期に比べ、各事例とも上下温度差が小さくな っている。頂部温度は、夏期ほどではないが、事例 1、6、 7、9、14、19H、20 のようにやや上昇する場合と、夜間 同様低下する場合とがみられる。前者は、夏期において も頂部温度がかなりの高温となる事例である。そして、 頂部以外についてみると、中層部から上層部については ほとんど上下温度差のない環境となっている。これは、 暖められた空気が上昇し、頂部で冷却され下降するとい う循環が起こっているためと考えられるが、Small type の ように比較的天井高の低いアトリウムでは、中層部にも 温度勾配がついており、日射の影響が伺える。一方、居 住域の温度は、 $20^{\circ}$ 前後の事例が多くなっているが、中 には $15^{\circ} \mathrm{C}$ るいは $25^{\circ} \mathrm{C}$ 近い事例も見られ、夏期に比べて、 冬期の方が使われ方に幅があるのではないかと考えられ る。また、多くの事例で居住域温度が、他の部分に比べ 低下しており、煙突効果の影響と考えられるが、特に事 例 $1 、 5 、 7 、 12 、 14 、 18$ での温度低下が目につく。これ らのアトリウムは、エントランスホールなど人の出入り の多い空間であり、外気侵入の影響だと思われる。また 事例 3 では、2 階部分の温度が低下している様子がみら れるが、これはこの位置にエントランスがあり、外気侵 入の影餖である。

\section{4. まとめ}

本研究によって得られた知見を以下にまとめる。 (1)1981 年 11 月〜 1994 年 4 月までの建築専門誌に基づく、 実施例の調㚗では、アトリウム総数は 216 件であった。 アトリウムの設けられた建物の用途は、事務所、複合施 設、宿泊施設、公共施設が多くなっている。全体の約 $40 \%$ 

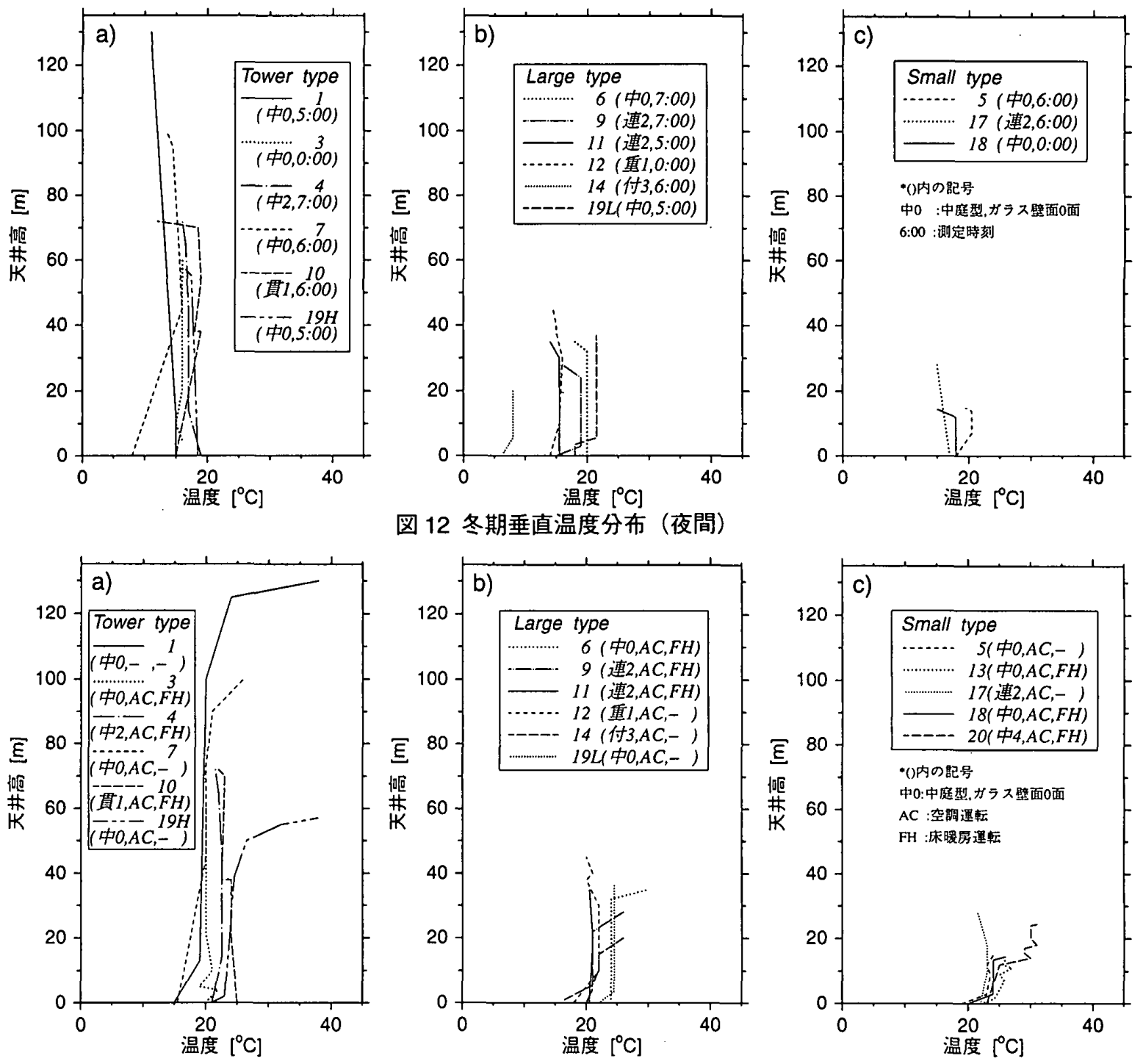

図 12 冬期垂直温度分布（夜間）
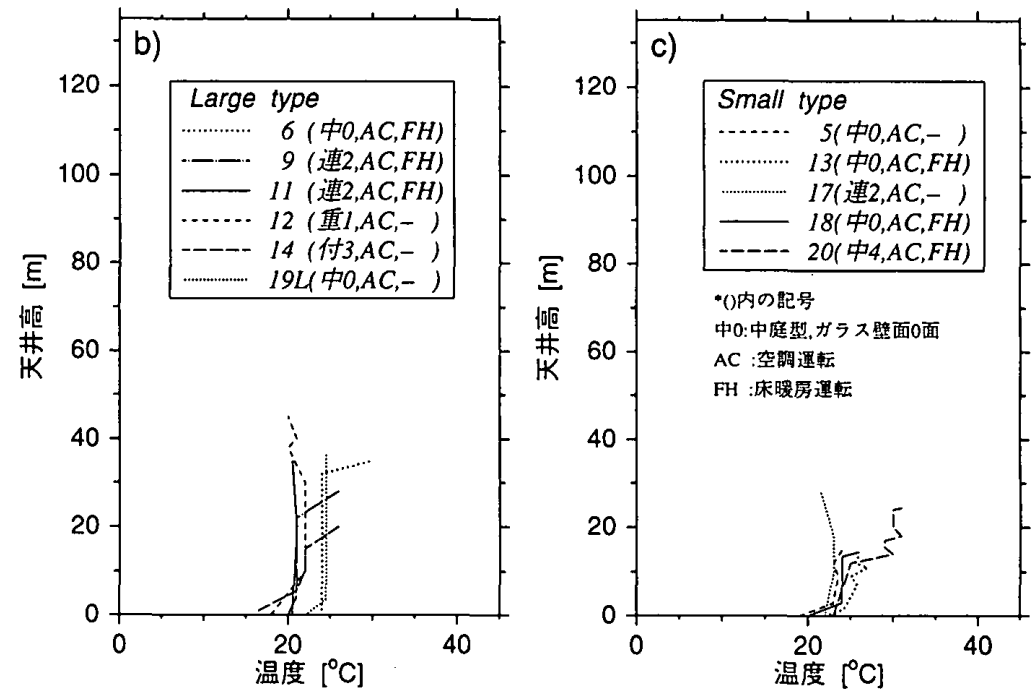

図 13 冬期垂直温度分布（日中）

は、中庭型の形態となっている。

(2)アトリウムの環境調整手法は、居住域空調、頂部での 排熱、ブラインド・遮蔽幕といった日射遮蔽が中心とな っており、機械設備に負うところが大きい。その一方で、 街路的空間とみなして、スポット空調とすることで空調 容量を低減している例や、自然換気の積極的な活用や建 築的な工夫によってのみ環境調整を行っている例も見ら れた。

(3)各事例の垂直温度分布の比較により、夏期の日中には 以下のような特徵がみられた。

a. 中庭型のアトリウムの内、高層の事例は、頂部がかな りの高温となるものの、熱だまり以外は、温度差が小さ く安定している。一方、低層の事例では、熱だまり以外 にも、緩やかな温度勾配が付く。

b. ガラス面の割合の大きな連接型、付加型のアトリウム では、アトリウム全体に渡って大きな温度成層が生じる。 c. 比較的低層で小規模な事例では、頂部での換気が行わ
れる事も多く、頂部温度の上昇は、比較的抑えられる。 $\mathrm{d}:$ 日射遮蔽、頂部での換気により、熱だまりにおける温 度上昇はかなり緩和される。

一方、冬期については、上下温度差がかなり小さくな るが、多くの事例で、居住域での温度低下が見られる。 特に、エントランスホールなど人の出入りの多い事例で、 温度低下が大きくなっている。また、比較的低層の事例 では、空間中部にも緩やかな温度差が付いており、日射 の影響が伺える。

注视

1) 本報は、日本建筑学会大会学術講演梗概集に発表した内容 ${ }^{30}$ を修 正・加筆したものである。

2）新建筑、建築文化、日経アーキテクテュア、ディテール。但し、揭 載される事例に偏りがある点を考虑する必要がある。

3) データの揃わない事例については除いている。

4) 事例 19 には、高層階、低層階に二つのアトリウムがあるため、そ れぞれ19H、19Lとしている。 


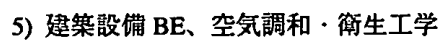

6) 参考文献 1) 29)。但し、事例 21 は、筆者らの実測による。

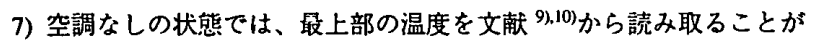
できなかった。

\section{参考文献}

1) 井上宇市ほか：吹抜大空間における温熱棵境に関する研究 第一報 実態調查,空気調和・衛生工学会学術論文集, pp.293 296, 1984.10 2) 小坂千里ほか:アトリウム杂間における熱瑔境の実測調査, 日本建築 学会大会学術講演梗概集, pp.807 808, 1989.10

3) 小林信行ほか：寒冷地におけるアトリウム渨境の実測調査(その1) 実測調查の概要, 日本建筇学会大会学術講演梗概集, pp.601 602, 1991.9 4) 䓓池世欧啓ほか:寒冾地におけるアトリウム摆境の実測調查(その3) アトリウムの鉛直温度分布, 日本建築学会大会学術䛱演梗概集, pp.605 $\sim 606,1991.10$

5) 塚本宏怡：アトリウムの温熱および光罧境計画,空気調和・街生工学, VOL.63, NO.9. pp.9 16, 1989

6) 戸河里敏ほか：オープンタイプ・アトリウムの熱環境（その1） 空調計画と熱棌境実測の概要, 日本建策学会大会学術講演梗概集, pp.591 -592, 1991.9

7) 高啝紀行ほか：大規模アトリウムの㻴境実測と評価（その1） 東京ベイホテル東急における実測䊅果（臬期）, 空気調和・衛生工学会 学衍䜊演会講演論文集, pp.509 512, 1991.10

8) 船津正菚ほか：大規模アトリウムの摆境実測と評価（その 2) 東京ベイホテル東急における実測結果 (冬期), 空気調和・衛生工学会 学術潇演会講演諭文集, pp.513 516, 1991.10

9) 石野久雿ほか：アトリウムをもつ建物の環境実測研究 第 2 報 アトリウム上下温度布と回廊部温熱愣境, 日本建築学会大会学術講演 梗概集, pp.817 818, 1992.8

10）石野久两ほか：アトリウムをもつ建物の環境実測研究 第 3 報 排気口, F C U 合却特性と探光特性, 日本建築学会大会学術講演梗概集, pp.819 820, 1992.8

11) 有吉㴡ほか:アトリウムの温熱嫄境 㕛期における内部温熱瓄境実 测調㚗, 㞬気調和・衞生工学会学術語演会講演論文集, pp. $521 \sim 524$, 1992.10

12）百瀬隆ほか:アトリウムの温熱瓄境に関する研究 建物概要と実測, 温熱理境制御,空気調和・衛生工学会学術講演会講演論文集, pp.525 $528,1992.10$

13）相賀洋ほか:オープンタイプアトリウムをもつ建物の温熱理境に関 する実測研究 第 1 報 建物特性と実测モード, 日本建築学会大会学術 潇演梗概集, pp.1463 1464, 1993.9

14) 谷口雄榯ほか:オープンタイプアトリウムをもつ建物の温熱瓄境に 関する実測研究 第 2 報 夏期におけるアトリウム上下温度分布及び 日射熱取得, 日本建筑学会大会学術講演梗概集, pp.1465 1466, 1993.9 15）伊藤直樹ほか:オープンタイプフトリウムをもつ建物の温熱摆境に 関する実測研究 第3 報 冬期における アトリウム上下温度分布及び 空気流入出性状, 日本建築学会大会学術講演梗概集, pp.1467 1468, 1993.9
16) 武田仁ほか：大森ベルホートフトリウムにおける理境測定と評価 第 1 報 居住域における外部の影響と垂直温度分布の実測調査,日本建 榮学会大会学術講演梗概集, pp.1599 1600, 1993.9

17）近藤靖史ほか：オーブン型アトリウムの温熱環境実測（その 1） 夏期の温・湿度分布,日本建築学会大会学術講演梗概集, pp.881 882, 1993.9

18）永瀬修ほか：オーブン型アトリウムの温熱環境実測（その 2） 冬期の温・湿度分布,日本建築学会大会学術講演梗概集, pp.883 884, 1993.9

19）鲤渕建造ほか：低居建物におけるアトリウム瑔境の実測調査（その

2）通常の空調時の温熱環境, 日本建築学会大会学術講演梗概集, pp.871 $>872,1993.9$

20）田中良和ほか：低層建物におけるアトリウム環境の実測調査（その

3）条件を变えた場合の温熱瑔境,日本建築学会大会学術講演梗概集, pp.873 874, 1993.9

21）西口賢一ほか: ガラス張りアトリウム空間における熱珙境実測調査, 空気調和 ·衛生工学会学術講演会講演論文集, pp.165 168, 1993.10

22) 原田剛ほか:西向きアトリウムの温熱環境実測及び数值計算との対

比（その1概要㧍よび実測結果）, 日本建築学会大会学術講演梗概

集, pp.631 632, 1994.9

23) 米田徳仁ほか: 自然温度型アトリウムの熱珢境 その1 温度計画 と空気温度分布の実測耛果,日本建築学会大会学術講演梗概集，pp.635 $\sim 636,1994.9$

24）中川浩之ほか：アトリウムの冷房・暖房時の温熱暞境実測調査,日 本建築学会大会学術講演梗概集, pp.933 934, 1994.9

25）梅津雅彦ほか：独身恭のアトリウム温熱瑔境の実測調查（その 4)

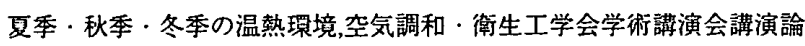
文集, pp.833 836, 1994.10

26）高橋雄司ほか：独身竂のアトリウム温熱環境の実測調查（その 5) 夏期の自然換気及び冬期の床暖房空調時の温熱環境,空気調和・衛生工 学会学術講演会講演論文集, pp.837 840, 1994.10

27) 吉村正孝ほか：密閉型アトリウムに拉ける温熱現境の解析と测定

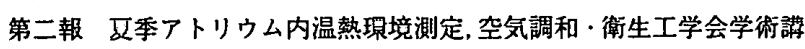
演会唡演論文箱, pp.821 824, 1994.10

28）吉村正孝ほか：密閉型アトリウムに扔ける温熱現境の解析と測定

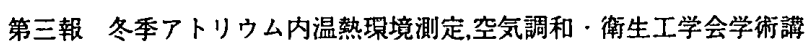
演会講演諭文集, pp.825 828, 1994.10

29) 平野功ほか: アトリウム温熱環境実測調査（弱期冬期実測結果及び PMV 制御の検証)，空気調和・衛生工学会学術講演会講演論文集, pp.829 $\sim 832,1994.10$

30）奇笹健,吉野博：アトリウムの温熱懪境に関する事例調査 垂直温 度分布と空間搆成との関連, 日本建築学会大会学術講演梗概集, pp.1269 $\sim 1270,1994.9$

31）吉野博：アトリウムを斬る,建箖雑誌，VOL.109, NO.1358, pp.20 21, 1994.6

32）日本建築学会編：アトリウムの摆境設計,㣏国社, 1994.1 33）リチャード・サクソン:アトリウム建築一発展とデザイン, 鹿島出 版会, 1988.10 